Naohiko Seki • Atsushi Hattori • Akiko Hayashi

Sumie Kozuma • Tada-aki Hori • Toshiyuki Saito

\title{
The human regulator of G-protein signaling protein 6 gene (RGS6) maps between markers WI-5202 and D14S277 on chromosome 14q24.3
}

Received: September 14, 1998 / Accepted: November 1, 1998

\begin{abstract}
The recently discovered regulators of G-protein signaling proteins, termed the RGS family, have been shown to modulate the functioning of G-proteins by activating the intrinsic guanosine triphosphatase (GTPase) activity of the $\alpha$ subunits. Here, we report the chromosomal location and tissue expression of the human regulator of $R G S 6$ gene. The messenger RNA was ubiquitously expressed in various tissues. Polymerase chain reaction (PCR)-based analysis with a human/rodent monochromosomal hybrid panel and a radiation hybrid panel indicated that the gene was mapped between genetic markers WI-5202 and D14S277 on chromosome 14q24.3 region.
\end{abstract}

Key words Regulators of G-protein signaling proteins · RGS6 · Chromosome mapping · Chromosome 14q24.3

\section{Introduction}

G-proteins are heterotrimers composed of single $\alpha, \beta$, and $\gamma$ subunits. The $\alpha$ subunits are guanine nucleotide-binding proteins that are regulated through cycles of guanosine triphosphate GTP and guanosine diphosphate (GDP) binding. In the inactive state, the $\alpha$ subunits are bound to GDP (for reviews, see Neer 1995; 1997). The recently discovered regulators of G-protein signaling proteins, termed the RGS family, have been shown to modulate the functioning of G-

N. Seki · A. Hattori $\cdot$ A. Hayashi $\cdot$ S. Kozuma $\cdot$ T. Hori · T. Saito $(\square)$ Genome Research Group, National Institute of Radiological Sciences, Anagawa 4-9-1, Inage-ku, Chiba 263-8555, Japan

Tel. +81-43-206-3135; Fax +81-43-251-9818

e-mail: t_saito@nirs.go.jp

N. Seki

Laboratory of Gene Function II, Kazusa DNA Research Institute, Chiba, Japan

A. Hattori

Biotechnology and Medical Engineering Field, Aisin Cosmos R\&D Co., Ltd., Tokyo, Japan proteins by activating the intrinsic GTPase activity of the $\alpha$ subunits (for reviews, see Dohlman and Thorner 1997; Koelle 1997; Neer 1997).

At present, full or partial sequences of the mRNAs for numerous putative RGS proteins have been identified in mammalian species (De Vries et al. 1995; Chen et al. 1996; Druey et al. 1996; Koelle and Horvitz, 1996; Siderovski et al. 1996; Gold et al. 1997; Snow et al. 1997; 1998; Seki et al. 1998a). The cDNA sequence of human RGS6 has recently been registered with the public database (accession number AF073920). We are attempting to carry out systematic chromosome mapping of signaling molecules including RGS5 (G-protein signaling regulator protein 5), ZIP kinase (serin/ threonine kinase gene), and KIP (kinase interacting protein) to contribute to positional candidate approaches (Seki et al. 1998a,b; Saito et al. 1998). We report here the expression profile and chromosomal localization of the human RGS6 gene.

\section{Expression profile of RGS6 gene}

We examined the tissue distribution of the transcript in various human tissues by reverse transcription-coupled polymerase chain reaction (RT-PCR). Primers used for RTPCR were to amplify the 533-bp cDNA of the transcript. Three amplified products, of 533-bp, 660-bp, and 765-bplong were finally detected, although it is yet to be determined whether they reflected alternatively spliced multiple messengers or distinct mRNAs derived from related genes. The products were not amplified in liver and were slightly detected in thymus and spleen, indicating that the expression of RGS6 may be suppressed or weakly promoted in such blood and lymphatic organs. In both fetal and adult brain, all three amplified products were obtained, suggesting the possible transcription of a brain-specific longer form. The shortest product was predominant in brains and heart, whereas the middle-sized product was abundant in the other tissues examined (Fig. 1). 
Chromosome mapping of RGS6 gene

Chromosomal assignment of RGS6 was done by PCR

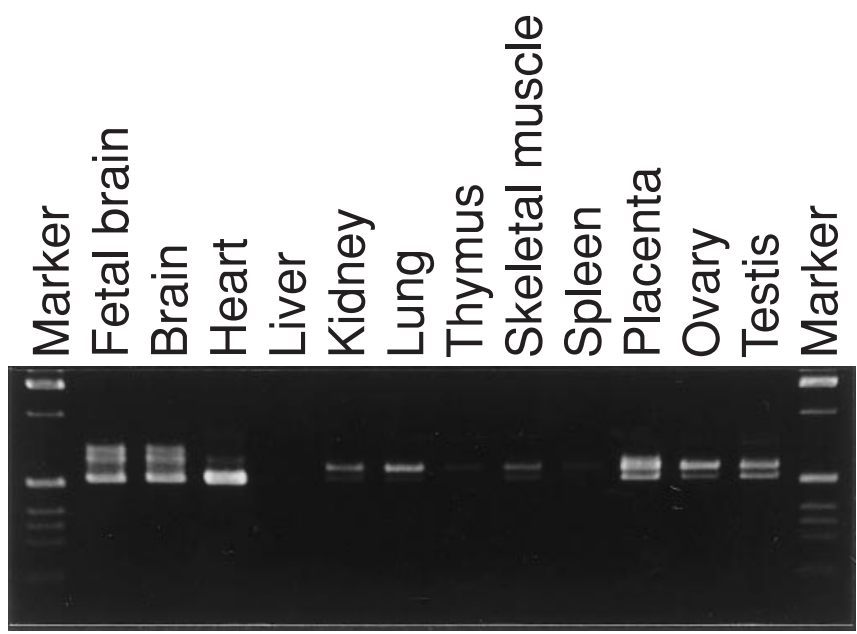

Fig. 1 Primers used for reverse transcription-coupled polymerase chain reaction (RT-PCR) were to amplify the 533-bp cDNA of the transcript. RT-PCR amplification primers were (5'-GGGGCGGGACCAGTTTCTACG- $\left.3^{\prime}\right)$ and (5'-CCCCACCATCGCCCTTCATTG-3'). It was confirmed that these primers gave no visible PCR product from genomic DNA. The templates of the human tissues of poly(A)+ RNAs were purchased from Clontech (Palo Alto, CA, USA). The cDNA templates for RT-PCR were synthesized from $2 \mu \mathrm{g}$ of poly (A)+, using excess amounts of Superscript II reverse transcriptase (GIBCO BRL, Gaithersburg, MD, USA) and random hexamer primers. PCR was carried out in a final volume of $10 \mu \mathrm{l} \mathrm{con-}$ taining $1 \times$ LA-PCR buffer (Takara, Kyoto, Japan), $2 \mu \mathrm{M}$ each primer, $200 \mu \mathrm{M}$ each dNTP, 50 ng template DNA, and 0.01 units of LA-Taq DNA polymerase (Takara). Temperature and time schedules were: 30 cycles at $95^{\circ} \mathrm{C}$ for $20 \mathrm{~s}$ and $64^{\circ} \mathrm{C}$ for $1 \mathrm{~min}$. PCR products were separated on $2 \%$ GTG gel (Takara) with a 1-kb ladder DNA marker (BRL, Gaithersburg, MD, USA)

Fig. 2 Chromosomal placement of the human RGS6 gene at a relative distance to framework markers on the WICGR radiation hybrid map of the human genome. The approximate corresponding cytogenetic location of the gene on chromosome $14 \mathrm{q} 24.3$ region is indicated. Distances are in centirays $(\mathrm{cR})$ from the top of the chromosome 14 linkage group

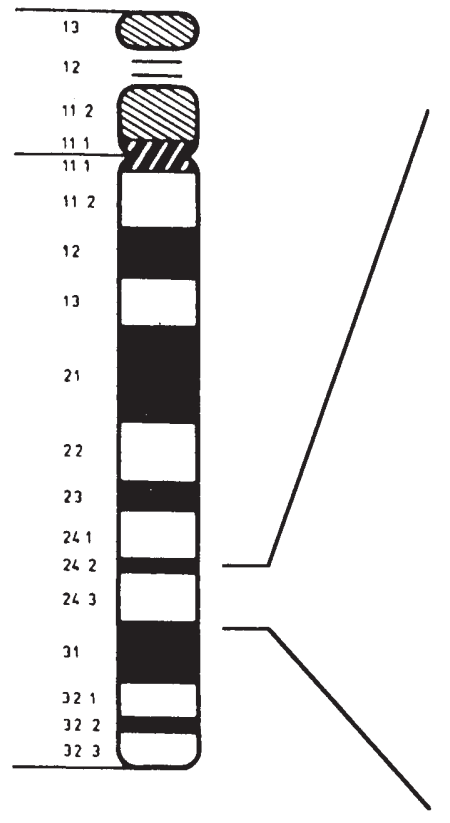

224.72

235.53

242.25

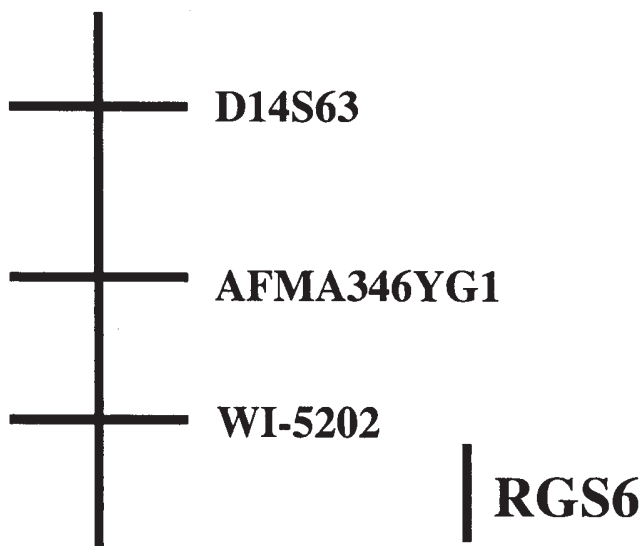

255.24

262.93

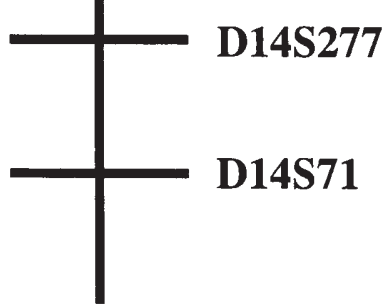

analysis of a human/rodent somatic cell hybrid panel and a radiation hybrid panel. The PCR primer set was designed for the $3^{\prime}$ untranslated region of the gene (5'-TAGGCAAGCTGGCGTGTGGAC-3', 5-CTATGCGCTCTCGTCCCCGTC-3', PCR product size, 110bp). DNA of the -rodent somatic cell hybrid panel was purchased Coriell Cell Repositories (Camden, NJ, USA). The specific amplified PCR product for human was detected only from the hybrid containing human chromosome 14 (data not shown). PCR was carried out as described previously (Saito et al. 1997; Seki et al. 1997). We performed further mapping analysis using a PCR-based radiation hybrid panel (Genebridge 4; Research Genetics, Huntsville, AL, USA) the same primers as those used in the assay for the /rodent somatic cell hybrid panel. Statistical analysis vector for the RGS6 gene was 00101001000000021010 (1000000211000100 001110000000010000010000010100 1he consequent report indied that the gene was mapped between markers WI-5202 D14S277, both of which have been cytogenetically cR distal from WI-5202 (lod > 3.0).

The region of chromosome 14q24.3 has been of particular interest, as it is known to contain one of the early-onset Alzheimer disease genes (AD3) (Sherrington et al. 1995). In the 14q24 region, several groups have reported the physical d transcription maps as a step toward identifying the zheimer disease gene or cosegregating with an anterior polar cataract (Cruts et al. 1995; Clark et al. 1995; Roux et al. 1997; Sharma et al. 1998). A goal of the Human Genome 
Project is the construction of a physical and transcription map of the human genome (Collins and Galas 1993). Our precise chromosomal positioning data for RGS6 the gene could contribute toward ongoing positional candidate approaches for the above-mentioned disease genes linked to this genomic locus.

\section{References}

Chen CK, Wieland T, Simon MI (1996) RGS-r, a retinal specific RGS protein, binds an intermediate conformation of transducin and enhances recycling. Proc Natl Acad Sci USA 93: 12885-12889

Clark RF, Cruts M, Korenblat KM, He C, Talbot C, Van Broeckhoven C, Goate AM (1995) A yeast artificial chromosome contig from human chromosome 14q24 spanning the Alzheimer's disease locus AD3. Hum Mol Genet 4: 1347-1354

Cruts M, Backhovens H, Theuns J, Clark RF, Le Paslier D, Weissenbach J, Goate AM, Martin JJ, Van Broeckhoven C (1995) Genetic and physical characterization of the early-onset Alzheimer's disease AD3 locus on chromosome 14q24.3. Hum Mol Genet 4: 1355-1364

Collins F, Galas D (1993) A new five-year plan for the U.S. Human Genome Project. Science 262: 43-46

De Vries L, Mousli M, Wurmser A, Farquhar MG (1995) GAIP, a protein that specifically interacts with the trimeric $G$ protein $G$ alpha i3, is a member of a protein family with a highly conserved core domain. Proc Natl Acad Sci USA 92: 11916-11920

Dohlman HG, Thorner J (1997) RGS proteins and signaling by heterotrimeric G proteins. J Biol Chem 272: 3871-3874

Druey KM, Blumer KJ, Kang VH, Kehrl JH (1996) Inhibition of Gprotein-mediated MAP kinase activation by a new mammalian gene family. Nature 379: 742-746

Gold SJ, Ni YG, Dohlman HG, Nestler EJ (1997) Regulators of Gprotein signaling (RGS) proteins: Region-specific expression of nine subtypes in rat brain. J Neurosci 17: 8024-8037

Koelle MR, Horvitz HR (1996) EGL-10 regulates G protein signaling in the $C$. elegans nervous system and shares a conserved domain with many mammalian proteins. Cell 84: $115-125$

Koelle MR (1997) A new family of G-protein regulators - the RGS proteins. Curr Opin Cell Biol. 9: 143-147

Neer EJ (1995) Heterotrimeric G proteins: Organizers of transmembrane signals. Cell 80: 249-257
Neer EJ (1997) Intracellular signalling: Turning down G-protein signals. Curr Biol 7: R31-R33

Roux AF, Rommens JM, Read L, Duncan AM, Cox DW (1997) Physical and transcription map in the region 14q24.3: Identification of six novel transcripts. Genomics 43:130-140

Saito T, Seki N, Ishii H, Ohira M, Hayashi A, Kozuma S, Hori T (1997) Complementary DNA cloning and chromosomal mapping of a novel phosphatidylinositol kinase gene. DNA Res. 4: 301-305

Saito T, Seki N, Ohira M, Hayashi A, Kozuma S, Hattori A, Hori T (1998) Assignment of the ZIP kinase gene to human chromosome 19 p13.3 by somatic hybrid analysis and fluorescence in situ hybridization. J Hum Genet 43: 209-211

Seki N, Nimura Y, Ohira M, Saito T, Ichimiya S, Nomura N, Nakagawara A (1997) Identification and chromosome assignment of a human gene encoding a novel phosphatidylinositol-3 kinase. DNA Res 4: 355-358

Seki N, Sugano S, Suzuki Y, Nakagawara A, Ohira M, Muramatsu M, Saito T, Hori T (1998a) Isolation, tissue expression, and chromosomal assignment of human RGS5, a novel G-protein signaling regulator gene. J Hum Genet 43: 202-205

Seki N, Hayashi A, Abe M, Araki R, Fujimori A, Fukumura R, Hattori A, Kozuma S, Ohira M, Hori T, Saito T (1998) Chromosomal assignment of the gene for human DNA-PKcs interacting protein (KIP) on chromosome 15q25.3-q26.1 by somatic hybrid analysis and fluorescence in situ hybridization. J Hum Genet 43: 275-277

Sharma V, Poorkaj P, Hisama F, Bonnycastle L, Yu CE, Massa H, Trask B, Clancy KP, Patterson D, Weissman SM, Schellenberg GD (1998) An expression map from human chromosome 14q24.3. Genomics 47: 314-318

Sherrington R, Rogaev EI, Liang Y, Rogaeva EA, Levesque G, Ikeda M, Chi H, Lin C, Li G, Holman K, Tsuda T, Mar L, Foncin JF, Bruni AC, Montesi MP, Sorbi S, Rainero I, PInessi L, Nee L, Chumakov I, Pollen D, Brookes A, Sanseau P, Polinsky RJ, Wasco W, Da Silva HAR, Haines JL, Pericak-Vance MA, Tanzi RE, Roses AD, Fraser PE, Rommens JM, St George-Hyslop PH (1995) Cloning of a gene bearing missense mutations in early-onset familial Alzheimer's disease. Nature 375: 754-760

Siderovski DP, Hessel A, Chung S, Mak TW, Tyers M (1996) A new family of regulators of G-protein-coupled receptors? Curr Biol 6: 211-212

Snow BE, Antonio L, Suggs S, Gutstein HB, Siderovski DP (1997) Molecular cloning and expression analysis of rat Rgs12 and Rgs14. Biochem Biophys Res Commun 233: 770-777

Snow BE, Antonio L, Suggs S, Siderovski DP (1998) Cloning of a retinally abundant regulator of G-protein signaling (RGS-r/RGS16): Genomic structure and chromosomal localization of the human gene. Gene 206: 247-253 